Archives of Agriculture and Environmental Science

\title{
Production oriented survey (POS) on different aspects of rice cultivation and farmers practices under red and lateritic zone of West Bengal, India
}

\author{
R. Mandal ${ }^{1}$, K. Jana ${ }^{2}$, S. Ghosh ${ }^{3}$, A. Biswas ${ }^{3}$, K.K. Bhadra ${ }^{3}$ and G.K. Mallick ${ }^{3}$ \\ ${ }^{1}$ Department of Plant Pathology and ${ }^{2}$ Department of Agronomy, Faculty of Agriculture, Bidhan Chandra Krishi Vishwavidyalaya, \\ Mohanpur - 741252, Nadia, (West Bengal), INDIA \\ ${ }^{3}$ Rice Research Station, Bankura- 722 101, (West Bengal), INDIA \\ *Corresponding author's E-mail: kjanarrs@gmail.com
}

\section{ARTICLE HISTORY}

Received: 30 October 2018

Revised received: 24 November 2018

Accepted: 26 November 2018

\section{Keywords}

Biotic stress

HYV and local rice varieties

Mono crop

Tropical monsoon climate

\begin{abstract}
Production Oriented Survey (POS) on rice cultivation was conducted by Rice Research Station, Bankura under programme of AICRIP, Directorate of Rice Research (ICAR), Rajendranagar, Hyderabad - 50003 during kharif, 2009 in Red and Laterite zone of West Bengal, India. Purulia, Bankura and some parts of Birbhum, Paschim Medinipur and Burtdwan districts that belongs to Red and Laterite zone of West Bengal. The popular commercial cultivars were Swarna (MTU 7029), Lalat, Jaya, CR 1010, CR 1017 and IR-64. Rice is cultivated as mono crop in this zone. The Indian sub-continent is predominantly characterized by a tropical monsoon climate which determines the success of kharif crops. Biotic constraints like blast, brown spot, sheath blight, sheath rot, grain dis-colouration and bacterial leaf blight (BLB) were in low to moderate intensities. Among insect pests brown plant hopper, green leaf hopper, stem borer, rice hispa and gundhi bugs were recorded in low to moderate intensities in the surveyed districts. Among weeds, Cyperus rotundus, Echinocloa crusgalli, Cyperus iria, Cynodon dactylan and Monochoria sp. were major problem in all the districts. The farmers used mainly hand weeding for control of weeds. Minimum use of pesticides and insecticides were observed.
\end{abstract}

(C)2018 Agriculture and Environmental Science Academy

Citation of this article: Mandal, R., Jana, K., Ghosh, S., Biswas, A., Bhadra, K.K. and Mallick, G.K. (2018). Production oriented survey (POS) on different aspects of rice cultivation and farmers practices under red and lateritic zone of West Bengal, India, Archives of Agriculture and Environmental Science, 3(4): 378-381, https://dx.doi.org/10.26832/24566632.2018.030408

\section{INTRODUCTION}

Production oriented survey (POS) on rice cultivation was conducted by Rice Research Station, Bankura under programme of AICRIP, Directorate of Rice Research (ICAR), Rajendranagar, Hyderabad-50003 during kharif, 2009 in Red and Laterite zone of West Bengal, India (Adhikari et al., 2011). The Indian sub-continent is predominantly characterized by a tropical monsoon climate which determines the success of kharif crops (Anonymous, 2009). There are two monsoon systems operating in the region (1) the south-west or summer monsoon and (2) the north-east or winter monsoon. The summer monsoon accounts for $70-80 \%$ of the annual rainfall over major parts of South Asia. There is a large variability in the monsoon rainfall on both space and time scales. Consequently, the Indian regions experiences drought-floods in some parts of the country or the other almost every year during the monsoon period between JuneSeptember. Drought in the Indian region is mainly due to various kinds of failure of rains from southwest monsoon (Laha et al., 2009). Also there seems to be some association between EI Nino and La Nina events and weak monsoons. The 'Aila' cyclone in the Bay of Bengal disturbed the normal monsoon pattern just after its setting in and discharged the system completely.

The cropping sequence was rice - rice, rice - wheat - vegetables, kharif rice - boro paddy, rice - mustard, rice - wheat, rice vegetables - wheat, rice - mustard - rice and others. Most of the farmers used cow dung and farm yard manure (FYM) as seed bed manuring. The application of basal fertilizers viz., $\mathrm{N}, \mathrm{P}_{2} \mathrm{O}_{5}$ and $\mathrm{K}_{2} \mathrm{O}$ were in less quantity. 


\section{MATERIALS AND METHODS}

\section{Description of study area}

In West Bengal, five districts that belongs to Red and Laterite zone namely Bankura, Purulia and some parts of Birbhum, Burdwan and Paschim Medinipur districts were surveyed during the kharif cropping season, 2009. Among five districts, twelve blocks and twenty nine village was surveyed thoroughly comprising thousand (1000)farmers (Table 1).

\section{Methodology and collection of data}

Production Oriented Survey (POS) was conducted by IIRR-ICAR in collaboration with SAU s and State Department of Agriculture on different aspects of rice cultivation in different rice growing states of Inda during the main crop season (June-July to November-December). The survey is based on both eye-ball survey and questionnaire based survey. The different aspects that are covered in the survey are prevailing climatic conditions for rice cultivation, varietal profile in a particular region, extent of use of organic manure and inorganic fertilizers, occurrence of different biotic and abiotic problems and their management and various needs of the farmers and problems faced by the farmers

\section{RESULTS AND DISCUSSION}

\section{District wise observations}

\section{Bankura}

This survey was conducted in seven villages in four different blocks of Bankura district. Majority of the farmer's population are marginal categories in the entire district. Date of transplanting was delayed due to delay in arrival of monsoon during this year. In this district rice was cultivated as a mono crop (single) in a year. But in few places boro paddy/mustard/wheat was cultivated due to availability of irrigation water. Nursery management and fertilizer application were not as per recommended practice. Farmer generally adopted random transplanting method. Among weeds Cyperus rotundus, Cyperus iria, Cyperus diformis, Echinochloa colona, were a major problem. Generally hand weeding was practiced. No herbicides were used to control the weeds. Regarding biotic stresses viz., low incidence of blast, sheath blight, sheath rot, bacterial leaf blight, false smut and grain discoloration were observed, infecting mostly high yielding varieties (Muralidharan et al., 2003). Among the insect pests namely stem borer, brown plant hopper, green leaf hopper, rice hispa and rice bug were prominent. But in low intensity it was observed that farmers generally did not follow standard methods of plant protection measures (Sharma et al., 2012). To control brown plant hopper, green leaf hopper, stem borer, acephate @ 1g per liter of water or triazophos @ 1ml per liter of water was practiced. To control diseases namely blast, sheath blight, hexaconazole or trycyclazole @ $1 \mathrm{ml}$ per liter of water was followed. Eighty per cent of rice grown areas of the district covered by high yielding variety like swarna (MTU 7029). Average yield during previous season was recorded 3.5 to $4 \mathrm{tha}^{-1}$.

\section{Purulia}

This district was surveyed during panicle initiation (PI) stage of rice. Due to water scarcity only rice was cultivated as a single crop in this year. Farmers generally depended on rainfed cultivation. Two varieties namely Lalat and Swarna (MTU 7029) were most important. Some of the farmers also cultivated local variety viz., Bhutmuri. Farmers did not follow the recommended Plant Protection measures to control either the disease or insect pests. Average yield of this region was 2.5 to $3.0 \mathrm{t} \mathrm{ha}^{-1}$.

\section{Birbhum}

This district was surveyed at dough stage of rice crop. In few places boro paddy was cultivated due to availability of irrigation water. Prevailing crop rotation of this district was rice - boro rice, rice - wheat, rice-mustard. Farmers used farm yard manure (FYM) in nursery bed as well as in the main field. Weed infestation was medium level in this district. The common weeds found were Cyperus irria, Cynodon dactylon, E. crusgalli. Hand weeding was practiced by most of the farmers. Among the disease blast, false smut, grain discoloration and sheath rot were observed. Farmers applied fungicides like Carbendazim @ 2 g per liter of water to control blast and sheath blight. Among insecticides, most of the farmers used acephate @ $1 \mathrm{~g}$ per liter of water to control plant hoppers (Srinivas et al., 2011).

Table 1. Particulars of survey in different districts, blocks and villages of West Bengal.

\begin{tabular}{|c|c|c|}
\hline District & Blocks & Villages \\
\hline Bankura & Indpur, Bankura -II, Chhatna and Barjoda & $\begin{array}{l}\text { Koyabadi, Bonkata, Pairachali,Kuanbaid,Saloni and } \\
\text { Inayatpur. }\end{array}$ \\
\hline Purulia & Kashipur and Hura & $\begin{array}{l}\text { Rangiladih, Chhatamora, Shikaripara, Ajwarpara, Debipur, } \\
\text { Rakhera and Bispuria. }\end{array}$ \\
\hline Birbhum & Imambazar & Ghurisa, Baruipur, Kamarpara, Mahisdhal and Belua. \\
\hline Burdwan & Asansol, Kulti, Kanksa. & $\begin{array}{l}\text { Moizla, Jomdoba, Kalla, Mahisala, Chinakuri and } \\
\text { Gopalpur. }\end{array}$ \\
\hline Paschim Medinipur & Daspur -I and Ghatal - II & $\begin{array}{l}\text { Paikan Duryodhan, Dadpur , Makarampur, Kismat } \\
\text { Kotalpur and Lachhipur. }\end{array}$ \\
\hline
\end{tabular}


Burdwan

It is one of the most important rice growing district of West Bengal. Some parts of this district that belongs to red and laterite zone of West Bengal (Table 3). It was surveyed at panicle initiation (PI) stage of rice crop. Majority of the farmers of this district were progressive farmers. Swarna (MTU 7029) which constituted 70 percent of the total rice grown area. Cultivation of few local Varieties viz., Raghusal, Banskati, Bhasamanik and Badsahbhog etc. were recorded in significant percentages. Farmers of this district used organic manure in the form of Farm yard manure (FYM) or compost @ 22 carts ha $^{-1}$ during main field preparation. Judicious use of fertilizer application was observed but not as per recommendation. Regarding biotic stresses, leaf blast, neck blast, false smut, grain discoloration, sheath blight, sheath rot were observed (Saha et al., 2008). Among insect pests viz., stem borer, brown plant hopper, gundhi bug, green leaf hopper were observed (Table 4). Farmers commonly practiced spraying of carbendazim, hexaconazole, propiconazole and validamycin for control of disease. Among insecticides acephate and furadan were used to control brown plant hoppers and stem borer. Average yield observed in the previous season was 4 to $5 \mathrm{tha}^{-1}$.

\section{Paschim Medinipur}

This district was surveyed at dough stage of rice crop. Generally rice was grown two or even three times in a year according to the availability of irrigation water. Weed infestation was medium in this district. Mainly Cyperus iria, Cyperus rotundus, E. colonum and Cynodon dactylon were predominant. Generally hand weeding was done. But some farmers apply Butachlor @1.5 kg a.i. ha $^{-1}$ within 3-5 days after transplanting. Farmers mainly cultivated Swarna (MTU 7029), IR-36, Lalat and Pankaj from high yield variety (HYV) category and Kabirajsal, Mugai and Gobindabhog etc. from local varieties. This year disease and pest incidence was low. Among the diseases blast, grain discolouration, false smut were observed (Upmanyu and Rana, 2013). Farmers generally used fungicides like carbendazim @ 2 g per liter of water and hexaconazole @ $1 \mathrm{ml}$ per liter of water to control blast and sheath blight. Insecticides like acephate @ 1g per liter of water was used to control plant hoppers (Prakasam et al., 2013).

In West Bengal five districts that belongs to red and laterite zone namely Bankura, Purulia, Birbhum, Burdwan, Paschim Medinipur were surveyed during the cropping season (Table 2). The farmers practiced late sowing in some of the districts surveyed. The surveyed farmers were progressive to sub-marginal also. The cropping sequence was rice-rice; ricewheat-vegetables; kharif rice - boro paddy, rice - mustard, rice wheat; rice-vegetables-rice and rice-mustard-rice and others. The popular commercial cultivars were Swarna (MTU 7029), Lalat, IR-36 and Khitish.

Table 2. Widely grown varieties in red and laterite zone of West Bengal.

\begin{tabular}{ll}
\hline Districts & Varieties \\
\hline Bankura & HYVs: Swarna (MTU7029), CR 1010, CR 1017, Lalat, IR 64 and PR 55 Local: Danaguri \\
Purulia & HYVs: Swarna (MTU7029), Lalat and Annada \\
& Local: Khandagiri and Bhutmuri \\
Burdwan & Local: Sitasal, Banskati, Vasamanik and Gobindabhog \\
& HYVs: Swarna (MTU7029), Lalat, IR 36, Khitish and Satabdi \\
Birbhum & Local: Mahsuri, Gobindabhog \\
& HYVs: Swarna (MTU7029, Lalat, IR 36, CR 1010, Pankaj and Shankar \\
Paschim Medinipur & Local: Mahsuri, Kabirajsal, Mugai and Gobindabhog \\
\hline
\end{tabular}

Table 3. Particular of rice Area in red and laterite zone of West Bengal.

\begin{tabular}{lll}
\hline Districts & Total rice area ('O00ha) & Irrigated area ('O00ha) \\
\hline Bankura & 316 & 145.3 \\
Purulia & 264 & 8.541 \\
Birbhum & 314 & 268.20 \\
Burdwan & 417 & 335.89 \\
Paschim Medinipur & 491 & -- \\
\hline
\end{tabular}

Table 4. Prevalence of diseases and insect pests in West Bengal-2.

\begin{tabular}{|c|c|c|c|c|c|c|c|c|c|c|c|c|}
\hline \multirow{2}{*}{ Districts } & \multicolumn{7}{|c|}{ Diseases } & \multicolumn{5}{|c|}{ Insect pest } \\
\hline & BS & NBL & BLB & FS & GD & ShBI & ShR & SB & $\mathrm{RH}$ & BPH & GB & GLH \\
\hline Bankura & $\mathrm{L}$ & - & $L$ & $L$ & $\mathrm{~L}$ & $L$ & $L$ & $\mathrm{~L}$ & $\mathrm{~L}$ & $L$ & $L$ & $\mathrm{~L}$ \\
\hline Purulia & $\mathrm{L}$ & - & - & - & $\mathrm{L}$ & - & L & - & $\mathrm{L}$ & $\mathrm{L}$ & L & $\mathrm{L}$ \\
\hline Birbhum & $\mathrm{L}$ & - & L & L & $\mathrm{L}$ & - & L & $\mathrm{L}$ & - & L & L & $\mathrm{L}$ \\
\hline Burdwan & $\mathrm{L}$ & L & $\mathrm{L}$ & $\mathrm{L}$ & $\mathrm{L}$ & $\mathrm{L}$ & L & $\mathrm{L}$ & - & L & L & $\mathrm{L}$ \\
\hline Paschim Medinipur & $\mathrm{L}$ & - & L & L & $\mathrm{L}$ & $\mathrm{L}$ & $\mathrm{L}$ & $\mathrm{L}$ & - & L & $\mathrm{L}$ & $\mathrm{L}$ \\
\hline
\end{tabular}

[BS - Brown Spot, NBL - Neck Blast, BLB - Bacterial Leaf Blight, FS - False Smut, GD - Glume Discoloration, ShBL - Sheath Blight , ShR - Sheath Rot, SB - Stem Borer, RH - Rice Hispa, BPH - Brown Plant Hopper, GB - Gundhi Bug, GLH - Green Leaf Hopper. ]. 


\section{Conclusion}

Rice is cultivated as mono crop under rainfed condition in Red and Laterite zone of West Bengal, India. In few places of this zone boro paddy is cultivated due to availability of irrigation water. High yielding varieties like Swarna (MTU 70219), Lalat, IR-36, CR-1010, CR-1017 cover more than $80 \%$ of total area under rice in this zone. The popular commercial traditional scented cultivar was Gobindabhog. Farmers did not follow the fertilizer Schedule as per recommendation. But cultivators in this zone adopted need based plant protection measures.

Open Access: This is an open access article distributed under the terms of the Creative Commons Attribution 4.0 License, which permits unrestricted use, distribution, and reproduction in any medium, provided the original author(s) if the sources are credited.

\section{REFERENCES}

Anonymous (2009). Production Oriented Survey, 2009. Annual Report, 2009: Rice Research Station, Bankura under Joint Director of Agriculture (M \& PP), West Bengal, Bankura.

Anonymous (2009). West Bengal -2 (Bankura). Production Oriented Survey, 2009. All India Coordinated Rice Improvement Programme. Directorate of Rice Research (ICAR), Rajendranagar, Hyderabad-500 030, India: 177-180.

Adhikari, B., Bag, M.K., Bhowmick, M.K. and Kundu, C. (2011). Status paper on rice in West Bengal. Rice (http://www. rkmp. co. in/), Rice Knowledge Management Portal (RKMP), Directorate of Rice Research, Rajendranagar, Hyderabad.

Directorate of Rice Research, Rajendranagar, Hyderabad
500030. pp. 1-88.

Laha, G.S. (2009). Survey, surveillance and production oriented survey. Compendium of Lectures, Winter School on Ecofriendly management of pests and diseases in rice and rice based cropping systems held at DRR, Hyderabad w.e.f. Sept. 15-Oct 5, 2009. pp. 191-197.

Muralidharan, K., Krishnaveni, D., Rajarajeswari, N.V.L and. Prasad. A.S.R. (2003). Tungro epidemics and yield losses in paddy fields in India. Current Science. 85(8): 11431147.

Prakasam, V., Ladhalakshmi, D., Laha, G.S., Krishnaveni, D., Madhav, S.M., Badri, J., Prasad, S.M. and Viraktamath, B.C. (2013). Sheath blight of rice and its management. Technical Bulletin No. 72, Directorate of Rice Research (ICAR),

Rajendranagar, Hyderabad - 500 030, A. P., India. pp. 58.

Saha, S., Dutta, A., Ghosh, S. and Mallick, G.K. (2008). Rice diseases in the red lateritic zone of West Bengal, India. Environment \& Ecology, 26 (4): 1691-1692.

Sharma, Pawan, K., Upmanyu, S., Srivastava, Ajai and Rana, S.K. (2012) Scenario of Insect -pests and Diseases of paddy in Himachal Pradesh. Agricultural Science Digest, 32(1): 71-74.

Srinivas Prasad M, Sheshu Madhav M, Laha GS, Ladha Lalshmi D, Krishnaveni D, Mangrauthia SK, Balachandran SM, Sundaram RM, Arunakranthi B, Madhan Mohan K, Ratna Madhavi K, Kumar V and Viraktamath BC. 2011. Rice blast disease and its management. Technical Bulletin No. 57. Directorate of Rice Research (ICAR), Rajendranagar, Hyderabad-500030, AP, India, pp. 52.

Upmanyu, S. and Rana, S.K. (2013). Status of false smut in major rice growing areas of Himachal Pradesh. Himachal Journal of Agricultural Research, 39 (2): 176-178. 